\title{
超小型衛星のミッション成否分析に基づく現状把握と将来予測*1 Current State and Future Forecast for Microsatellites Based on Success and Failure Analysis of Their Space Missions
}

\author{
石 井亮 介*2 ·佐 原宏 典*3 \\ Ryosuke IsHII and Hironori SAHARA
}

\begin{abstract}
Key Words : Mission Result Analysis, Multiple Classification, Logistic Regression, Principle Component, CubeSat
\end{abstract}
\begin{abstract}
We conducted various sorts of multiple classification analysis concerning CubeSats primarily developed by universities, based on information published on papers and websites. Single regression analysis led to a future forecast of the numbers of CubeSat launches, and logistic regression analysis predicted accomplishment probability of minimum and full success levels by CubeSats being launched on 2011. Furthermore, we clarified positions of the experienced countries of CubeSat launches, and indicated the direction they should progress for their developments. Thus, we here propose information sharing and collaborative development for beneficial change of CubeSat's success rate.
\end{abstract}

\section{1.は じめに}

宇宙開発は冷戦構造の中では国家の威信を掛けた事業で あり, 衛星の大型化に伴うその開発期間の長期化と開発費 の肥大化が 1990 年代まで続いたが，冷戦の終結と共に費用 対効果が強く意識されるようになった。その状況の中で予 算の削減, 開発期間の短縮を実現しつつ, 質の高いミッショ ンを行う “Smaller, faster, better, cheaper”という新たな 流れが生じ, より規模の小さな衛星が提起されるようになっ た1)。1995 年には Stanford University's Space Systems Development Laboratory（SSDL）において人工衛星開発 プロジェクト OPAL が立ち上がった2). OPAL は母衛星の 内部に搭載した 6 個のピコサットクラス（質量 $0.1 〜 1 \mathrm{~kg}$ ) の娘衛星を軌道上で放出する母娘衛星の実証が主要なミッ ションであり, 低コスト, 短期間での衛星開発を目指した。 このプロジェクトで得た知見を受けて, 短期開発, 低コス トを満たす衛星として SSDL の B. Twiggs 教授は 1999 年 の University Space Systems Symposium (USSS) にお いて, 1 辺 $10 \mathrm{~cm}$, 質量 $1 \mathrm{~kg}$ の超小型衛星 CubeSat を提 唱した. CubeSatは大学にとって衛星開発が可能な規模で あるため, 多くの大学が CubeSat の開発に参加を表明し た。そして 2003 年 6 月 30 日, 東京大学の XI-IV ${ }^{3)}$ と東京 工業大学の CUTE-I ${ }^{4)}$ を含む 6 機の CubeSat が打ち上げ られた。この瞬間, 大学による衛星開発の実現性が実証さ れ，世界各国で大学による超小型衛星開発が盛んに行われ るようになった。

しかしながら現在の大学における CubeSatの開発, 運 用は教育目的という側面が強いため, ミッション成否に対

\footnotetext{
*1 (C) 2012 日本航空宇宙学会

平成 23 年 3 月 7 日原稿受付

*2 首都大学東京システムデザイン研究科航空宇宙システム工学域

*3 首都大学東京システムデザイン学部航空宇宙システム工学コース
}

する関心が低い傾向にあることは，その成功基準の第一を 「学生の手による衛星開発, 打上」に設定する事例が少なく ないことからも垣間見える。そのため不具合が発生しても 原因の究明が専門的かつ熱心に行われず, 解決策や防止策 が示されることが少ないのが現状である. 不具合原因の究 明はその衛星のみならず，次機開発の際にも非常に重要な 情報となる. 更に大学では学生の世代交代が頻繁に発生し, 衛星開発に関する情報が蓄積, 継承されにくいため, 自ら が得た知見を文書化する等が重要になるが，不具合原因を 特定する手段を心得ていない場合が多く，情報の蓄積は限 定的となっている.

そこで本研究では特に CubeSatに焦点を当てた統計的 分析を行うことによって現状把握と将来予測を行い, その 傾向や問題点を抽出する。また, 実績の少ない国が実績の 多い国と共同で開発した場合の予測を示すことで, 情報や 実績を共有することの有効性を示す.

\section{2. 統計的分析方法}

人工衛星の開発能力が未成熟な大学や新規参入の企業が 打ち上げた CubeSat を対象として, 論文や文献, ウェブ サイト等から収集した公開情報を用いて統計的分析を行う. 本研究では主に複数の指標を元に, その指標同士の関係性 を分析する多変量解析法を用いて情報を分析する。

2.1 単回帰分析 ある $n$ 個のデー夕組を散布図に描い たとき直線的な分布

$$
y_{i}=\beta_{0}+\beta_{1} x_{i, 1}+\beta_{2} x_{i, 2}+\cdots+\beta_{p} x_{i, p}+\varepsilon_{i}
$$

が想定されたとする。ここで $x_{i, j}(i=1,2, \cdots, n ; j=1$, $2, \cdots, p)$ 及び $y_{i}$ は実測された説明変数及び目的変数, $\beta_{j}$ は回帰係数, $\varepsilon_{i}$ は誤差項である. 式 $(1)$ の回帰式は説明変 数が $p$ 個の場合の一般的なものであるが, ここでは $p=1$ 
の単回帰分析について話を進め, 以下では $x_{i, 1} \equiv x_{i}$ と表 記する. 最小二乗法を用いれば最小二乗推定値 $\hat{\beta}_{0}, \hat{\beta}_{1}$ は,

$$
\begin{aligned}
& \hat{\beta}_{0}=\bar{y}-\hat{\beta}_{1} \bar{x} \\
& \hat{\beta}_{1}=\frac{S_{x y}}{S_{x x}}
\end{aligned}
$$

と求まり，回帰式を得る。ここで $\bar{x}, \bar{y}$ はそれぞれの平均 值であり,

$$
\begin{aligned}
& S_{x y}=\sum_{i=1}^{n}\left(x_{i}-\bar{x}\right)\left(y_{i}-\bar{y}\right) \\
& S_{x x}=\sum_{i=1}^{n}\left(x_{i}-\bar{x}\right)^{2}
\end{aligned}
$$

である，推定された回帰式の精度を示す指標として寄与率 $R^{2}$ を用いる。ここで $R^{2}$ は,

$$
\begin{aligned}
& S_{R}=\hat{\beta}_{1} S_{x y} \\
& S_{y y}=\sum_{i=1}^{n}\left(y_{i}-\bar{y}\right)^{2} \\
& S_{e}=\sum_{i=1}^{n} e_{i}^{2}=S_{y y}-\hat{\beta}_{1} S_{x y}, \quad e_{i}=\hat{y}_{i}-y_{i}
\end{aligned}
$$

を用いて

$$
R^{2}=\frac{S_{R}}{S_{y y}}=1-\frac{S_{e}}{S_{y y}}
$$

と定義される。 $e_{i}$ は残差, $\hat{y}_{i}$ は回帰式で得られる推定值で ある. 誤差 $\varepsilon$ の分散は次のように推定できる.

$$
\hat{\sigma}^{2}=V_{e}=\frac{S_{e}}{n-2}
$$

また，分析結果の妥当性を検証するために標準化残差

$$
e_{i}^{\prime}=\frac{e_{i}}{\sqrt{V_{e}}}
$$

を導入する。標準化偏差は標準正規分布に近似的に従い, こ の值の絶対值が 3.0 以上であればそのデー夕を除外すべき と判断する. また, 各説明変数を横軸に取り, $e_{i}^{\prime}$ を散布図 に描いたとき，分布が無規則であるように見えることを確 認する。

2.2 ロジスティック回帰分析 ロジスティック回帰分析 はデー夕の持つ情報からある現象の発生確率を求める手法 であり, $p$ 個の説明変数 $x_{i, j}$ に対して目的変数 $y_{i}$ が 1 とな る確率 $P_{i}$ が 0 から 1 の間を取る次式でモデルを想定する.

$$
\begin{aligned}
\log \frac{P_{i}}{1-P_{i}} & =\beta_{0}+\beta_{1} x_{i, 1}+\beta_{2} x_{i, 2}+\cdots+\beta_{p} x_{i, p} \\
& \equiv z_{i}
\end{aligned}
$$

最尤法を用いれば，尤度関数及び対数尤度関数はそれぞれ 式 (13), (14) で表される.

$$
\begin{aligned}
\prod_{i=1}^{n} P_{i}^{y_{i}}\left(1-P_{i}\right)^{1-y_{i}} & =\prod_{i=1}^{n}\left(\frac{P_{i}}{1-P_{i}}\right)^{y_{i}}\left(1-P_{i}\right) \\
& =\prod_{i=1}^{n} e^{z_{i} y_{i}} \frac{1}{1+e^{z_{i}}}
\end{aligned}
$$

$$
L=\sum_{i=1}^{n} z_{i} y_{i}-\sum_{i=1}^{n} \log \left(1+e^{z_{i}}\right)
$$

ここで式 (14)を各 $\beta_{j}$ でそれぞれ偏微分してできる連立方 程式を解けば各 $\beta_{j}$ が求まるので, 式 (12) より確率の推定 值 $\hat{P}_{i}$ を得る.

ところで説明変数の選択は $\chi^{2}$ 検定や尤度比検定等様々 な方法があるが，ここでは Akaike's Information Criteria （AIC）を用いる. AIC は,

$$
\mathrm{AIC}=-2\left\{L_{\max }-(p+1)\right\}
$$

で求められ，この值が最小となる説明変数の組み合わせを 採用する，また，各説明変数が意味のある変数であるか否 かをワルド検定を用いて検証する。ワルド検定では帰無仮 説として回帰係数 $\hat{\beta}_{j}=0$ を仮定し, se を標準誤差である として検定統計量

$$
\chi_{\mathrm{Wald}}^{2}=\frac{\beta}{\operatorname{se}(\beta)}
$$

の $P$ 值が有意水準より小さいことを確認する.

次にデータの中に外れ值が無いことを標準化残差

$$
\varepsilon_{i}=\frac{y_{i}-\hat{P}_{i}}{\sqrt{\hat{P}_{i}\left(1-\hat{P}_{i}\right)}}
$$

を用いて確認する， $\varepsilon_{i}$ が 3.0 以上のデー夕は異質なものと して除外する。

2.3 主成分分析 主成分分析では互いに相関のある変数 について, 収集されたデー夕の持つ情報をできるだけ損な わないように次元を圧縮し，新たな指標を作りだす手法で ある、いま簡単のため変数 $x$ が 2 個の場合を考える。第一 主成分 $z_{1}$ はデー夕の持つ情報の損失が最小となる方向, 即 ちデータの分散が最も大きくなる方向の軸なので, 分散 $V_{z_{1}}$ を最大にすることを目指す， $z_{1}$ を倸数 $a_{1}, a_{2}$ を用いて，

$$
z_{1}=a_{1} u_{1}+a_{2} u_{2}
$$

と扔く。ここで,

$$
u_{1}=\frac{x_{1}-\bar{x}_{1}}{s_{1}}, \quad u_{2}=\frac{x_{2}-\bar{x}_{2}}{s_{2}}
$$

であり, 変数 $x_{1}, x_{2}$ をそれぞれの標準偏差 $s_{1}, s_{2}$ によっ て標準化したものである。これにより標準化変数の平均は $\bar{u}_{1}=\bar{u}_{2}=0$, 標準化残差は $V_{u_{1}}=V_{u_{2}}=1$ となり,

$$
\begin{aligned}
& \bar{z}_{1}=0 \\
& \sum_{i=1}^{n} u_{1, i}^{2}=\sum_{i=1}^{n} u_{2, i}^{2}=n-1 \\
& \sum_{i=1}^{n} u_{1, i}^{2} u_{2, i}^{2}=(n-1) r_{x_{1} x_{2}}
\end{aligned}
$$

となるので式 $(20) \sim(22)$ を用いて $V_{z_{1}}$ を求めると, 


$$
\begin{aligned}
V_{z_{1}} & =\frac{1}{n-1} \sum_{i=1}^{n}\left(z_{1, i}-\bar{z}_{1}\right)^{2} \\
& =a_{1}^{2}+a_{2}^{2}+2 r_{x_{1} x_{2}} a_{1} a_{2}
\end{aligned}
$$

$r_{x_{1} x_{2}}$ は添字に記載の変数同士の相関係数である.ここで 制約条件を $a_{1}^{2}+a_{2}^{2}=1$ とし, ラグランジュの未定乗数法 を用いて $V_{z_{1}}$ の最大值を求める. 未定乗数を $\lambda$ として,

$$
\begin{aligned}
f\left(a_{1}, a_{2}, \lambda\right)= & a_{1}^{2}+a_{2}^{2}+2 r_{x_{1} x_{2}} a_{1} a_{2} \\
& -\lambda\left(a_{1}^{2}+a_{2}^{2}-1\right)
\end{aligned}
$$

とし，式 $(24) を a_{1} ， a_{2}$ で偏微分して整理すれば,

$$
\left[\begin{array}{cc}
1 & r_{x_{1} x_{2}} \\
r_{x_{1} x_{2}} & 1
\end{array}\right]\left[\begin{array}{l}
a_{1} \\
a_{2}
\end{array}\right]=\lambda\left[\begin{array}{l}
a_{1} \\
a_{2}
\end{array}\right]
$$

という固有値問題に帰着する。式 (25) に左から $\left[\begin{array}{ll}a_{1} & a_{2}\end{array}\right]$ を掛けると，

$$
V_{z_{1}}=\lambda
$$

となるので, 結局 $\lambda$ の最大值を求めることになる. 即ち, 最大の固有值 $\lambda_{1}$ のときの固有ベクトル $\left[\begin{array}{ll}a_{1} & a_{2}\end{array}\right]^{\mathrm{T}}$ を求め れば $z_{1}$ を求めることができる，また，異なる固有值に対応 する固有べクトルは互いに直交しているため， 2 番目に大 きな固有値に対応する固有ベクトルから第二主成分 $z_{2}$ を 求めることができる，それぞれの主成分は当初用いた変数 $x$ の意味を鑑み，合理的にその意味を解釈する。

\section{3. 集 計 結 果}

3.1 情報収集と集計方法 本研究では超小型衛星の内, 2011 年 3 月時点で公知されている CubeSat を情報収集対 象として選択した. CubeSatは多くの大学が衛星開発の入 門的な位置付けで開発するため, その開発組織は大学をは じめとするアマチュア団体の比率が高い。 また, 最近になっ て盛り上がっている衛星であるためウェブ上に情報が豊富に あるという利点がある。情報収集では宇宙機関や衛星メー カー等のものも含め, これらの大学等のアマチュア団体へ の技術移転を踏まえて打上数には計上するが，ミッション の達成状況に関しては特に大学衛星のみを対象とし, 宇宙 機関や衛星メーカーは評価の対象外 (Out of evaluation) としている。これは宇宙機関等のミッションが非常に高度 かつ高価な技術実証や軍事利用であるため, 大学等のミッ ションとは単純に比較できないためである。情報収集の方 法としては，超小型衛星に関する文献や各 CubeSatに関す る論文, ウェブサイトを元に各項目 (衛星名・開発国・運 用組織・打上日・打上ロケット・質量・サイズ・ミニマム サクセス達成状況・フルサクセス達成状況）の収集を行っ た、な㧍、ミニマムサクセス，フルサクセスについては開 発団体によってその難易度の設定が様々であるため, 本研 究では次の統一基準を設定した

・ミニマムサクセス：軌道上の衛星が発したビーコン等の 送信デー夕を継続的に受信する。但し，運用チームが成
第 1 表 集計項目と集計方法

\begin{tabular}{ll}
\hline \multicolumn{1}{c}{ 単純集計 } & \multicolumn{1}{c}{ クロス集計 } \\
\hline 年別 CubeSat 打上数 & 年-ロケット別 CubeSat 打上数 \\
国別 CubeSat 打上数 & 年-国別 CubeSat 打上数 \\
ロケット別 CubeSat 打上数 & ロケット別ミニマム/フルサクセス \\
& 達成数 \\
ミニマムサクセス達成割合 & 年別ミニマム/フルサクセス達成数 \\
フルサクセス達成割合 & 国別ミニマム/フルサクセス達成数 \\
\hline
\end{tabular}

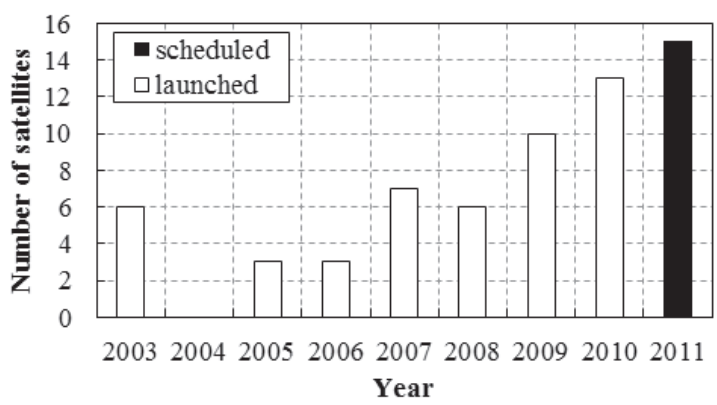

第 1 図 年別 CubeSat 打上数

功基準を公表し，ミニマムサクセスの項目に軌道上ミッ ションを含む場合はその基準に従う。

・フルサクセス：衛星の掲げるミッションをすべて達成す る。但し，運用チームが成功基準を公表し，フルサクセ スの項目が存在する場合はその基準に従う.

データの集計は単純集計とクロス集計とに分けて行う. 第 1 表にそれぞれの集計項目を示し，分析方法は以下のよ うに選択する。

- 単回帰分析：年別打上数に扔ける将来打上数予測

・ロジスティック回帰分析：ミッション達成確率予測 ·主成分分析：国別 CubeSat 打上数，ミニマムサクセス達 成数，フルサクセス達成数のそれぞれの関係抽出 なお，クロス集計に执いてもミッションの達成状況が含ま れるものに関しては大学衛星のみを対象とし, 宇宙機関や 衛星メーカーは評価の対象外 (Out of evaluation) として いる.

\section{2 単純集計結果}

年別 CubeSat 打上数 : 年別の CubeSat 打上数を第 1 図 に示す. 1999 年にCubeSat プロジェクトが開始され，2003 年に第一陣の CubeSat 打上が実現した。2004 年には 1 機 も打ち上げられていないが 2005 年以降は継続的に増加傾 向にあり，2010 年には 10 機を超えた. 2010 年までに 48 機の CubeSat が打ち上げられており，2011年には現時点 で判明しているだけで 15 機の打上が予定されている.

国別 CubeSat 打上数：国別にCubeSat 打上数を集計し た結果を第 2 図に示す。 2010 年までに打ち上げられた 48 機の CubeSat の内, アメリカが全体のほぼ半分の $48 \%$ を 占め, 次いで日本 $(21 \%)$, ドイッ $(9 \%)$ と続き, 以降に はヨーロッパ諸国，カナダ，コロンビアが並ぶ、ロシアや 中国が含まれていないことから, CubeSat の開発は西側諸 国が中心となっていることが分かる.

ロケット別 CubeSat 打上数：ロケット別の CubeSat 打 


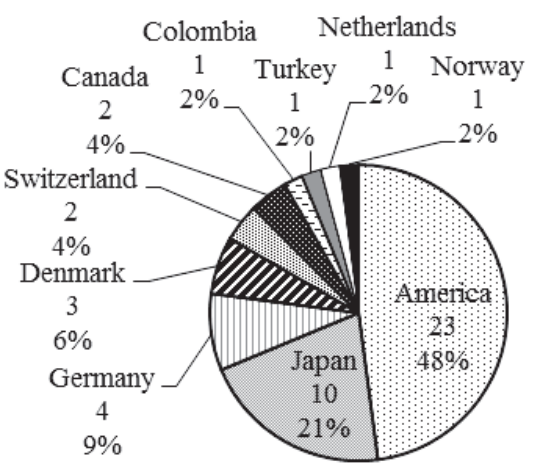

第 2 図 国別 CubeSat 打上数

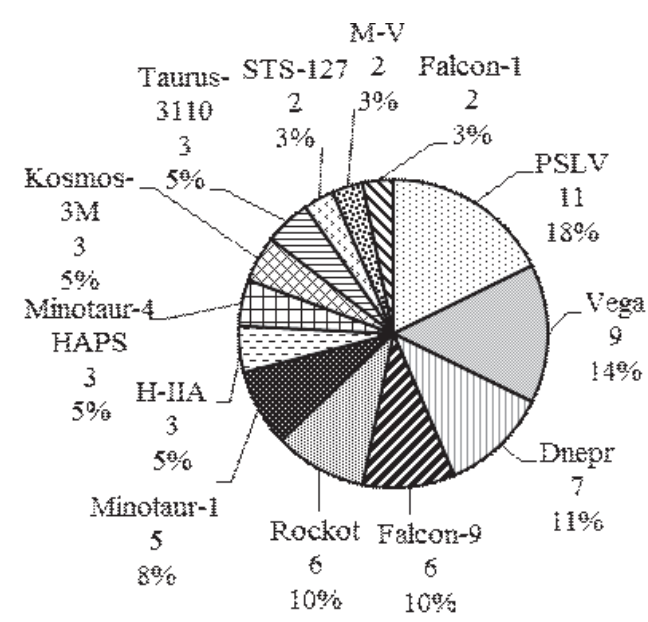

第 3 図 ロケット別 CubeSat 打上数

上数を第 3 図に示す。ここでは 2011 年打上予定の Vega, Falcon-1, Taurus-3110を含んでいる。但し，2011年打上 予定の CubeSat の中で 1 機だけは打上ロケットが未定で あるため，これを除外している。従ってここでは 62 機の CubeSat が対象となっている. 第 3 図を見ればインドの PSLV が最多の $18 \%$ となっているが，これはロシアの打上 費用の高騰の状況の中で PSLV の打上費用が他よりも安 いことから多くの利用があったものと考えられる。次いで ESA (European Space Agency) の Vega (14\%), ウク ライナの Dnepr（11\%）が続く. 日本の H-IIA や M-V も 利用されて抢り, 更にスペースシャトルからの放出もなさ れる等, 多種多様な手段で CubeSat が軌道に投入されて 扮り，既に打上手段の分散化がかなり進んでいることが分 かる。

ミニマムサクセス達成割合：評価対象である大学による CubeSat は 35 機であり, そのミニマムサクセス達成割合 を第 4 図に示す。ミニマムサクセスを達成した CubeSat は 29 機で全体の $83 \%$ であった。 また，1機については打上後 の情報を発見できなかったため, 不明（Unknown）と評価 した。

フルサクセス達成割合：同じく評価対象である 35 機の CubeSat のフルサクセス達成割合を第 5 図に示す。フルサ クセスを達成した CubeSat は 10 機で全体の $29 \%$ あっっ
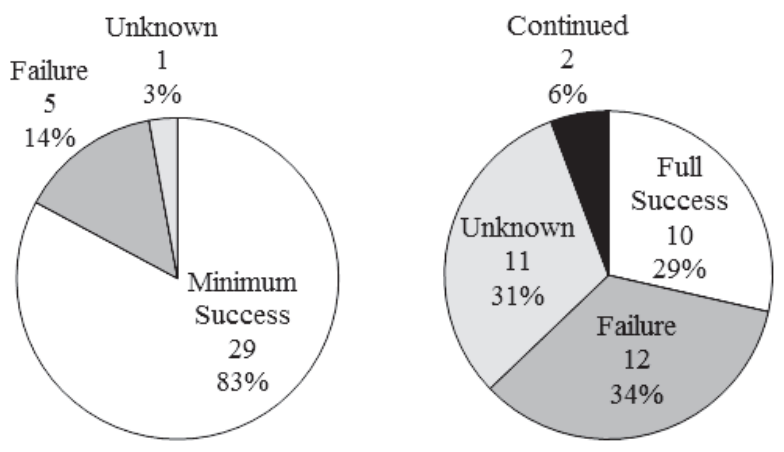

第 4 図 ミニマムサクセス達成割合

第 5 図 フルサクセス達成割合

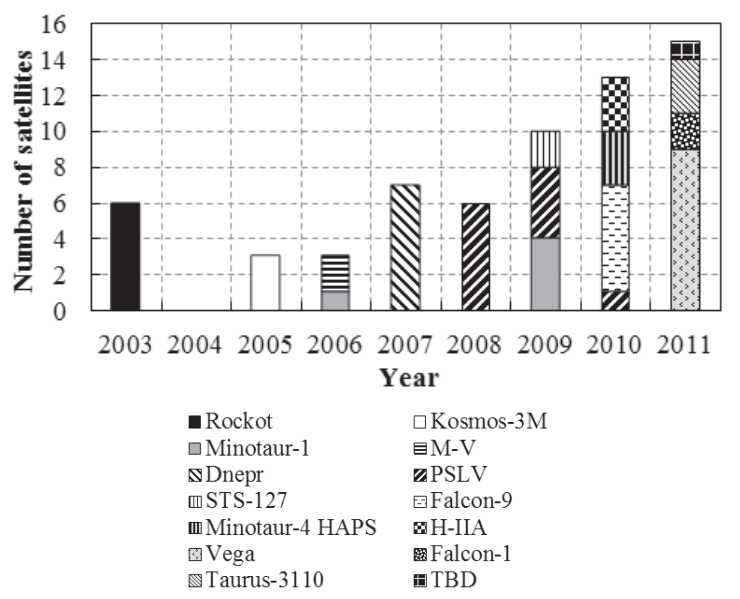

第 6 図 年-ロケット別 CubeSat 打上数

た．失敗は 12 機で全体の $34 \%$ 占めている。また，ミ二 マムサクセスは達成したがフルサクセスを達成できなかっ たものは 7 機であった。な拉，フルサクセス達成に関する 情報が発見できなかったものは 11 機と多く, 成功・失敗 のいずれも数は増える可能性がある。ミッションを継続中 (Continued) の 2 機については 2010 年後半に打ち上げら れたもので, 2011 年 1 月現在も成否の結果は出ていない.

\section{3 クロス集計結果}

年一ロケット別 CubeSat 打上数：ロケット別の CubeSat 打上数を年ごとに集計したものを第 6 図に示す. 2003 年の CubeSat 初打上にはロシアの Rockot が, 2005 年には同 じくロシアの Kosmos-3M が利用された．2006 年には赤外 線天文衛星「あかり」と共に $\mathrm{M}-\mathrm{V}$ に搭載され，2008 年か らはPSLV が 3 年連続で使用された。 2011 年には打上予 定の 15 機の内, 9 機の CubeSat が Vegaにより打上予定 である。なお，2006 年には Dneprによって 14 機の打上が 試みられたが，ロケットの失敗により軌道に投入されるこ とはなかった。

年-国別 CubeSat 打上数: 国別の CubeSat 打上数を年ご とに集計したものを第 7 図に示す。棟は 2003 年の CubeSat 初打上から継続的に打上を行って㧍り，2010 年までに 10 機が打ち上げられた。一方アメリカは 2005 年と 2008 年 には打上が無かったものの, 2007 年から年間打上機数を増 加させて抢り，現在までに 23 機の打上がなされた。アメリ 


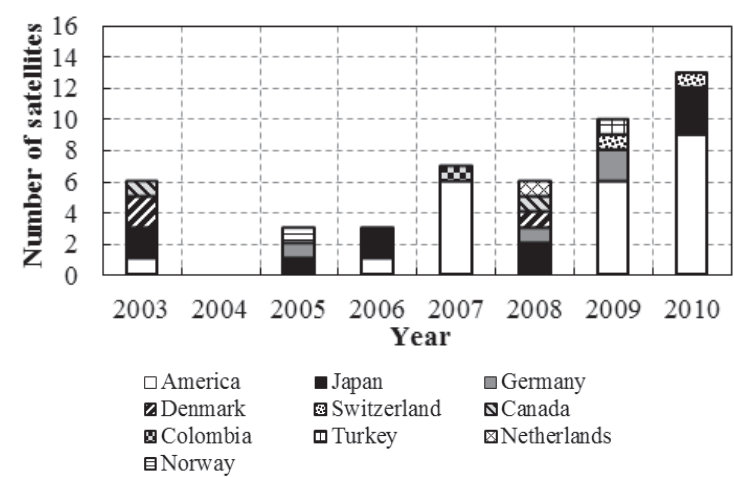

第 7 図 年-国別 CubeSat 打上数

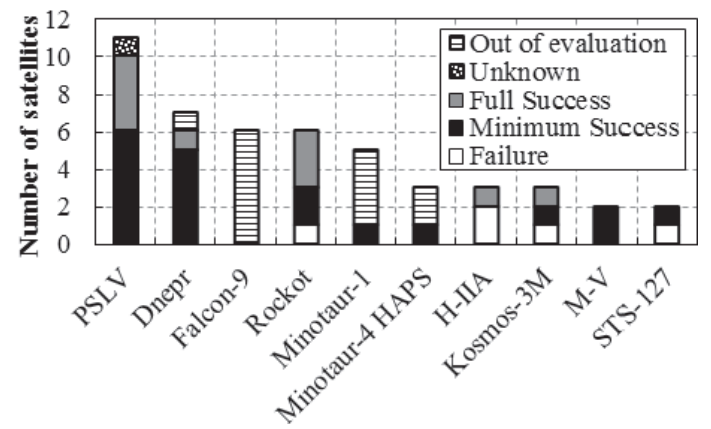

第 8 図 ロケット別ミニマム/フルサクセス達成数

カはNASA (National Aeronautics and Space Administration）が CubeSatの開発に積極的であり，例えば QbX シリーズは 2009 年 9 月時点で 12 機が製作され，2010 年 に既に 2 機が打ち上げられたことに加え，更に 20〜50 機 の追加開発が計画されている状況にあり, 今後も年間打上 数は増加すると予想される.

ロケット別ミニマム/フルサクセス達成数：ロケット別に ミニマム/フルサクセスの達成状況を集計したものを第 8 図 に示す。ここではミニマムサクセスを達成したがフルサク セスを達成できなかった衛星数をミニマムサクセス数に含 め, ミニマム/フルサクセスを共に達成した衛星数をフルサ クセス達成数としている. 評価対象外 (Out of evaluation) の 13 機はいずれもアメリカが開発した衛星である。また, 情報不足または現在ミッション継続中のため評価外となっ ている衛星は Unknown として分類している. 第 6 図と合 わせて見れば，ミニマムサクセスを達成できなかった衛星 (Failure) は, 1 回の衛星の打上数が少ないロケットに集中 していることが見て取れる。言い換えれば 1 回の衛星の打 上数が多いロケットは衛星のミニマムサクセス達成数が多 いことになるが，その理由として，打上延期によって衛星 の追試験の機会があったことや，ある一定の技術段階にあ る衛星を採択したコーディネータの手腕によること等も考 えられ5)，相関や因果を断言することはできない．

年別ミニマム/フルサクセス達成数: 年別にミニマム/フ ルサクセスの達成状況を集計したものを第 9 図に示す。近 年の打上数増加は前述の通り NASA 等の影響が大きい. 前 項と同じくUnknown となっている衛星が幾つかあり，そ
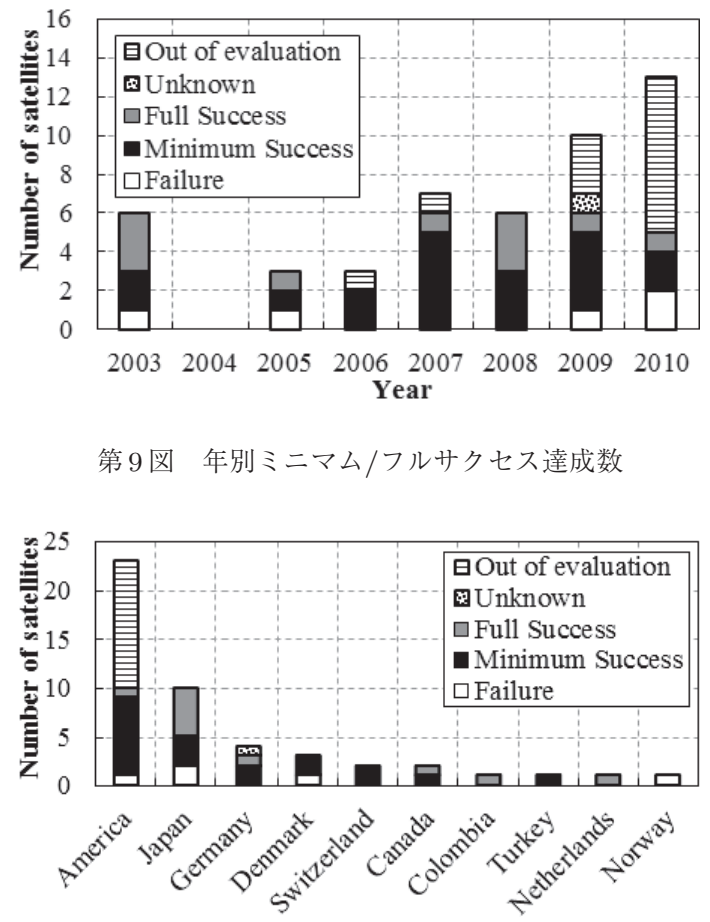

第 10 図 国別ミニマム/フルサクセス達成数

の成否によって達成数は変化すると考えられるが，増加す る打上数に応じた達成数を得ているとは言い難く, 年を経 るごとにミッション達成状況の改善が成されているとは言 えない.

国別ミニマム/フルサクセス達成数: 国別にミニマム/フ ルサクセスの達成状況を集計したものを第 10 図に示す。ア メリカの CubeSat 打上数の半数以上が NASA やメーカー が開発した衛星であることが分かる。また，打上数とフル サクセス達成率には相関が見られない。

\section{4. 分 析 結 果}

以上のように集計した結果を用いて本節ではそれらの統 計的分析を行い，現状把握及び将来推定を行う。また，そ の結果から見て取れる傾向や問題点を抽出する。

4.1 将来の年間打上数予測 第 1 図で得た集計を元に, 将来に㧈ける CubeSat の打上数を予測する。ここでは説明 変数 $x$ は年, 目的関数 $y$ は衛星打上数を表し, 回帰式は 以下のように求まった。

$$
y=\hat{\beta}_{0}+\hat{\beta}_{1} x=-4008+2 x
$$

このとき寄与率 $R^{2}=0.933$ となり, 強い相関があること を確認した。また， $x=x_{0}$ に扔ける信頼率 $95 \%$ の予測区 間は,

$$
\begin{aligned}
& \hat{\beta}_{0}+\hat{\beta}_{1} x_{0} \\
& \pm t(n-2, \quad 0.05) \sqrt{\left\{1+\frac{1}{n}+\frac{\left(x_{0}-\bar{x}\right)^{2}}{S_{x x}}\right\} V_{e}}
\end{aligned}
$$

から求められる. 以上より求めた回帰直線と予測区間を第 11 図に示す. 2011 年の打上数予測は 10〜 18 機と予測され, 


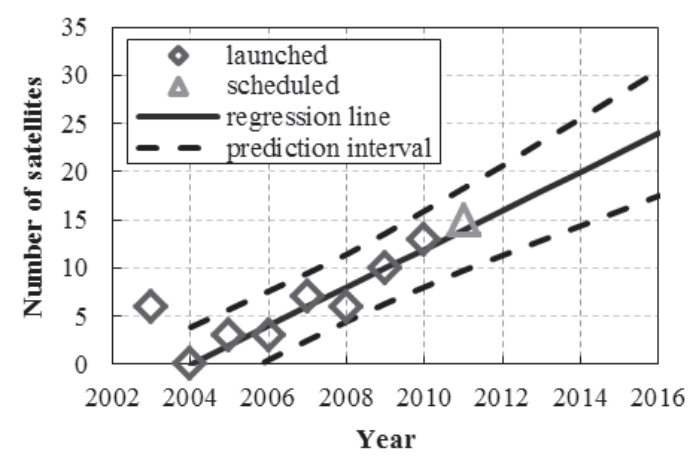

第 11 図 将来の年間打上数予測

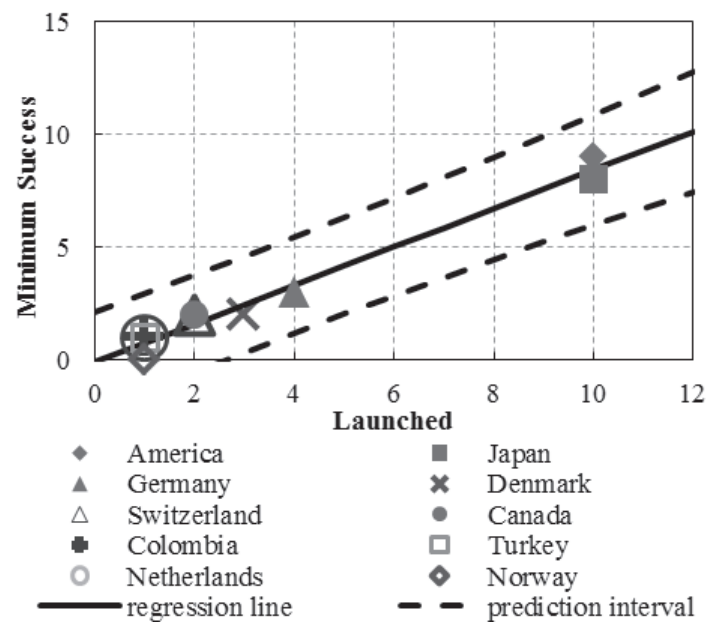

第 12 図 国別打上数-ミニマムサクセス達成数の予測

これは現時点での予定である 15 機と適合する. 直線的な打 上数の増加が見られることは CubeSat の順調な滑り出し の時期を経験していることを示しているが, 現在の参加団 体の結果が呼び水となって更に CubeSatを開発する国や団 体が拡大して発展がなされるためには，この直線及び予測 区間よりも上を行くことを目指すことが一つの目標となる.

4.2 国別打上数一ミニマムサクセス達成数 説明変数 $x$ を国別打上数, 目的変数 $y$ をミニマムサクセス達成数とし て単回帰分析を行った結果, 回帰式は次のように求まった。

$$
y=\hat{\beta}_{0}+\hat{\beta}_{1} x=-0.08+0.852 x
$$

このとき寄与率 $R^{2}=0.9779$ となり, 強い相関があること を確認した. 即ち, 各国の打上数に対するミニマムサクセ ス達成数は一定の割合に留まっており, 打上数の多い国が 必ずしもミニマムサクセスの達成率が高いとは言えず, 打 上数の多少にかかわらずミニマムサクセス達成率の改善が 表れていないことを示している，回帰直線に予測区間を加 えた結果を第 12 図に示す. CubeSatの発展のためには少 なくとも最低限の成功基準であるミニマムサクセスを達成 する必要があり, 図中の直線や予測区間を上回ることを目 指す必要がある。

4.3 ミッション達成確率予測 ロジスティック回帰分析 により, ミッション達成状況の評価対象である 35 機の大学 によるCubeSatの集計結果を用いて，2011 年打上予定の

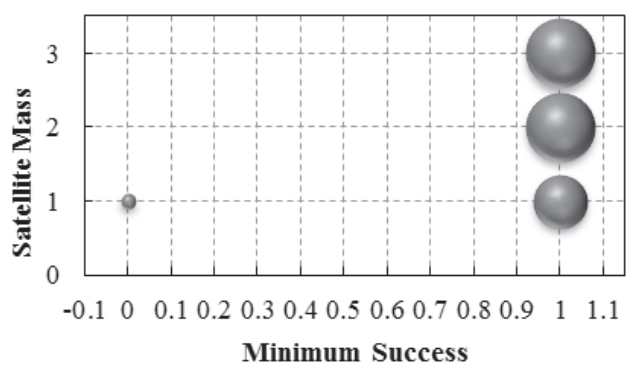

第 13 図 質量とミニマムサクセス達成率の関係

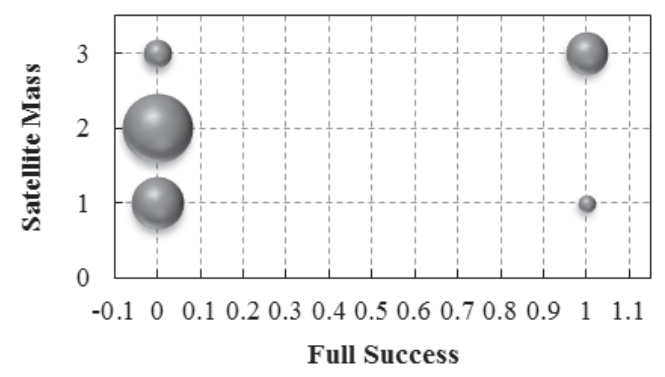

第 14 図 質量とフルサクセス達成率の関係

CubeSatについてミッション達成確率を予測する。ミニマ ムサクセス達成確率の予測には質量別及び国別のミニマム サクセス達成率を, フルサクセス達成確率の予測には質量 別及び国別のフルサクセス達成率をそれぞれ使用する。な お，達成率と達成確率とを混同しないよう留意する。

第 13 図及び第 14 図の横軸は 0 を失敗, 1 を成功として 質量別に衛星の機数を集計し，その質量におけるミニマム/ フルサクセスの達成率を球の大きさで表している．質量別 のミニマムサクセス達成率は第 13 図から質量が大きいほ ど達成率が高くなっており，一方フルサクセス達成率は第 14 図から質量が小さいほど達成率が高い傾向がある。

ミニマムサクセス，フルサクセス達成確率のそれぞれに おいて対数尤度関数

$$
\begin{aligned}
L= & \sum_{i=1}^{n} z_{i} y_{i}-\sum_{i=1}^{n} \log \left(1+e^{z_{i}}\right) \\
= & \sum_{i=1}^{n}\left(\beta_{0}+\beta_{1} x_{i 1}+\beta_{2} x_{i 2}\right) y_{i} \\
& -\sum_{i=1}^{n} \log \left(1+e^{\beta_{0}+\beta_{1} x_{i 1}+\beta_{2} x_{i 2}}\right)
\end{aligned}
$$

が最大となる $\beta_{0}, \beta_{1}, \beta_{2}$ を求めることによって, ミニマム サクセス, フルサクセスの達成確率の予測值 $P_{M}, P_{F}$ は,

$$
\begin{aligned}
& P_{M}=\frac{1}{1+\exp \left\{-\left(-54.92+7.55 x_{1}+63.93 x_{2}\right)\right\}} \\
& P_{F}=\frac{1}{1+\exp \left\{-\left(-7.27+9.67 x_{1}+10.22 x_{2}\right)\right\}}
\end{aligned}
$$

から求まる。 ここでミニマムサクセス，フルサクセスのそ 
れぞれに対して $x_{1}$ を国別達成率， $x_{2}$ を質量別達成率と した。ミニマムサクセス及びフルサクセスの達成確率の誤 判別率は $5 / 35=0.143$ 及び $6 / 35=0.171$ となり, 問題 無い. また, 尤度比検定を行った結果， $\chi^{2}$ 值はそれぞれ 8.17, 19.38 であり, 有意水準 $95 \%$ の自由度 2 における $\chi^{2}$ 值 5.99 を上回っていることから $\hat{\beta}_{1}=\hat{\beta}_{2}=0$ ではない.

以上で求まった予測式を用いて, 2011 年打上予定の CubeSatについてミッション達成状況を予測した結果を第 2 表に 示す. 打上予定の 15 機の内, 13 機がシングルタイプ $(10 \mathrm{~cm}$ 角, 表中 $\square$ ), 2 機がトリプルタイプ (シングルタイプの 3 倍長, 表中回）である。アメリカ, ドイッ, ノルウェー 以外は新規参入国（表中では網掛けで示す）であり，それ らの国々は過去のデータが無く予測不可能であるため評価 対象外とした。 また，ノルウェーについては過去の実績が 1 機しかないため, 予測の精度は十分であるとは言い難い ことに留意するべきである。ミッション達成確率が $50 \%$ を 超えているものを成功, 下回ったものを失敗として評価す ると, 過去に打上実績のある国の衛星 7 機の内の 6 機がミ ニマムサクセスを達成する。一方, フルサクセスについて は達成する衛星は 0 機であるという厳しい予測となった.

ここで，ノルウェーについて考える。ノルウェーはこれま でにCubeSat の打上経験はあるものの, 成功経験は未だ無 い. 従って予測の精度は十分であるとは言い難いことを念 頭におきつつも，ミニマムサクセス達成確率ですら $1 \%$ と非 常に厳しい予測となっている。ところがもしノルウェーが 世界平均レベルの実績を有すると仮定し，これを統計上は 打上数とミニマム/フルサクセス達成数の世界的な平均值を ノルウェーが有しているとすれば，ミニマムサクセス達成 確率及びフルサクセス達成確率はそれぞれ $83 \%$ 及び $13 \%$ に 向上する。これは世界的にはミニマムサクセス達成率が高 いことに起因する。あるいはノルウェーが日本と共同で開 発すると仮定し, 統計上は日本とノルウェーを合計した実 績を有しているとすれば，ミニマムサクセス達成確率及び フルサクセス達成確率はそれぞれ $69 \%$ 及び $45 \%$ に向上す る。これは日本のフルサクセス達成率が高いことが寄与し

第 2 表 データの収集項目と集計方法

\begin{tabular}{|c|c|c|c|c|}
\hline 衛星名 & 国 名 & タイプ & $\begin{array}{c}\text { ミニマムサクセス } \\
\text { 達成確率 }\end{array}$ & $\begin{array}{c}\text { フルサクセス } \\
\text { 達成確率 }\end{array}$ \\
\hline AtmoCube 1 & イタリア & $\square$ & $\# \mathrm{~N} / \mathrm{A}$ & $\# \mathrm{~N} / \mathrm{A}$ \\
\hline E1P & アメリカ & $\square$ & $89 \%$ & $2 \%$ \\
\hline e-st@r & イタリア & $\square$ & $\# \mathrm{~N} / \mathrm{A}$ & $\# \mathrm{~N} / \mathrm{A}$ \\
\hline Goliat & ルーマニア & $\square$ & $\# \mathrm{~N} / \mathrm{A}$ & $\# \mathrm{~N} / \mathrm{A}$ \\
\hline HEIDELSAT & ドイツ & $\square$ & $73 \%$ & $9 \%$ \\
\hline HERMES & アメリカ & $\square$ & $89 \%$ & $2 \%$ \\
\hline HiNCube & ノルウェー & $\square$ & $1 \%(83 \% / 69 \%)$ & $1 \%(13 \% / 45 \%$ \\
\hline InnoSat & マレーシア & $\square \square \square$ & $\# \mathrm{~N} / \mathrm{A}$ & \#N/A \\
\hline KySat 1 & アメリカ & $\square$ & $89 \%$ & $2 \%$ \\
\hline Lightsail 1 & アメリカ & $\square \square \square$ & $100 \%$ & $39 \%$ \\
\hline OUFTI 1 & ベルギー & $\square$ & $\# \mathrm{~N} / \mathrm{A}$ & $\# \mathrm{~N} / \mathrm{A}$ \\
\hline PW-Sat 1 & ポーランド & $\square$ & $\# \mathrm{~N} / \mathrm{A}$ & $\# \mathrm{~N} / \mathrm{A}$ \\
\hline ROBUSTA & フランス & $\square$ & $\# \mathrm{~N} / \mathrm{A}$ & $\# \mathrm{~N} / \mathrm{A}$ \\
\hline UNICubeSAT & イタリア & $\square$ & $\# \mathrm{~N} / \mathrm{A}$ & $\# \mathrm{~N} / \mathrm{A}$ \\
\hline UWE-3 & ドイツ & $\square$ & $73 \%$ & $9 \%$ \\
\hline ミミシション達成 & 戌数予測 & & $6 / 7$ & $0 / 7$ \\
\hline
\end{tabular}

ている。このことは共同開発によって新規参入国や成績不 振の国が大きく成長し，そして全体の成績が向上すれば更 に全体の成績が向上することを意味している.

4.4 主成分分析による国別の特徵 第 10 図における 各国の特徵をその国の CubeSat 開発者の多さ, 開発した CubeSatの質という観点から総合評価する. 開発者の多さ は打上数に, CubeSatの質はミニマム/フルサクセス達成 数に反映されるものと見なす。第一主成分 $z_{1}$, 第二主成分 $z_{2}$ をそれぞれ，

$$
\begin{aligned}
& z_{1}=a_{11} u_{1}+a_{12} u_{2}+a_{13} u_{3} \\
& z_{2}=a_{21} u_{1}+a_{22} u_{2}+a_{23} u_{3}
\end{aligned}
$$

としたとき, $u_{1}, u_{2}, u_{3}$ はそれぞれ国別打上数, ミニマム サクセス達成数, フルサクセス達成数を標準化した值を示 す. 相関行列 $R$ を求めると,

$$
\begin{aligned}
R & =\left[\begin{array}{ccc}
1 & r_{x_{1} x_{2}} & r_{x_{1} x_{3}} \\
r_{x_{2} x_{1}} & 1 & r_{x_{2} x_{3}} \\
r_{x_{3} x_{1}} & r_{x_{3} x_{2}} & 1
\end{array}\right] \\
& =\left[\begin{array}{ccc}
1 & 0.989 & 0.690 \\
0.989 & 1 & 0.655 \\
0.690 & 0.655 & 1
\end{array}\right]
\end{aligned}
$$

となり，固有值と固有ベクトルはそれぞれ，

$$
\begin{aligned}
{\left[\begin{array}{lll}
\lambda_{1} & \lambda_{2} & \lambda_{3}
\end{array}\right]^{\mathrm{T}} } & =\left[\begin{array}{lll}
2.566 & 0.424 & 0.010
\end{array}\right]^{\mathrm{T}} \\
{\left[\begin{array}{lll}
\boldsymbol{a}_{1} & \boldsymbol{a}_{2} & \boldsymbol{a}_{3}
\end{array}\right]=} & {\left[\begin{array}{ccc}
a_{11} & a_{12} & a_{13} \\
a_{21} & a_{22} & a_{23} \\
a_{31} & a_{32} & a_{33}
\end{array}\right] } \\
= & {\left[\begin{array}{ccc}
0.608 & 0.331 & 0.722 \\
0.601 & 0.402 & -0.691 \\
0.519 & -0.854 & -0.046
\end{array}\right] }
\end{aligned}
$$

となった。また，因子負荷量は次式で表される。

$$
\begin{aligned}
{\left[\begin{array}{lll}
r_{z_{1} x_{1}} & r_{z_{2} x_{1}} & r_{z_{3} x_{1}} \\
r_{z_{1} x_{2}} & r_{z_{2} x_{2}} & r_{z_{3} x_{2}} \\
r_{z_{1} x_{3}} & r_{z_{2} x_{3}} & r_{z_{3} x_{3}}
\end{array}\right]=} & {\left[\begin{array}{ccc}
\sqrt{\lambda_{1}} a_{11} & \sqrt{\lambda_{2}} a_{12} & \sqrt{\lambda_{3}} a_{13} \\
\sqrt{\lambda_{1}} a_{21} & \sqrt{\lambda_{2}} a_{22} & \sqrt{\lambda_{3}} a_{23} \\
\sqrt{\lambda_{1}} a_{31} & \sqrt{\lambda_{2}} a_{32} & \sqrt{\lambda_{3}} a_{33}
\end{array}\right] } \\
= & {\left[\begin{array}{ccc}
0.974 & 0.216 & 0.072 \\
0.963 & 0.262 & -0.069 \\
0.831 & -0.556 & -0.005
\end{array}\right] }
\end{aligned}
$$

以上から国別打上数, ミニマムサクセス達成数, フルサクセ 又達成数の因子負荷量の第一主成分と第二主成分の值を用 いてその位置 $\left(r_{z_{1} x_{1}}, r_{z_{2} x_{1}}\right),\left(r_{z_{1} x_{2}}, r_{z_{2} x_{2}}\right),\left(r_{z_{1} x_{3}}, r_{z_{2} x_{3}}\right)$ を描いたものを第 15 図に示す。また, 各国のデー夕におけ る第一主成分と第二主成分を求め, 散布図に描いたものを 第 16 図に示す.

第 15 図において打上数とミニマムサクセス達成数の点 がほぼ同じ位置にあるが，これはミニマムサクセス達成確 


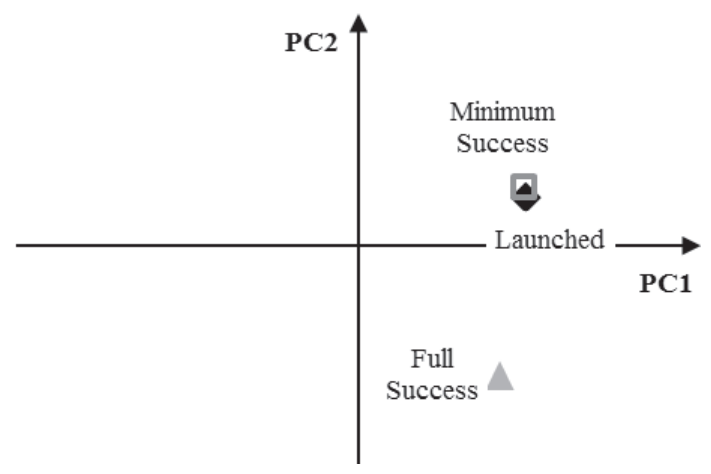

第 15 図因子負荷量の位置

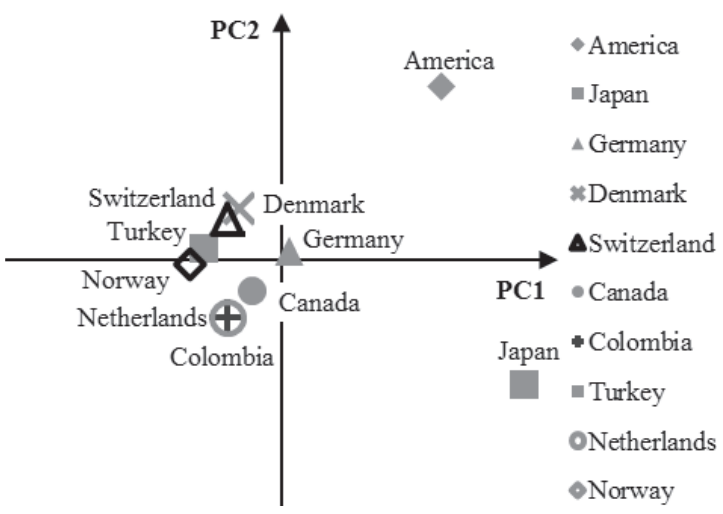

第16 図 国別の総合評価

率が 9 割と高く, 打上数とミニマムサクセス達成数の值が 近いことに起因する。これより第 16 図の横軸である第一 主成分は式 (33), (38) から各説明変数の数が大きくなるほ ど軸の正向きに進むため, 総合評価を示していると見なせ る. また, 各説明変数に扔いて評価の比重は打上数とミニ マムサクセス達成数がほぼ同等であり, フルサクセスを達 成することによる評価の比重が他の 2 つのパラメータと比 較して低くなっている。しかし実際にはミニマムサクセス を達成しなけ机ばフルサクセスを達成できないので，フル サクセスを達成した場合はミニマムサクセス＋フルサクセ スの評価と考えることができる. 即ち, 打上数が多く, か つフルサクセスを多く達成しているほど総合評価が高くな る. 従って第 16 図に扒いて, 打上数とミニマムサクセス達 成数により評価された国は上平面に，フルサクセス達成数 により評価された国は下平面に位置する。総合評価に㧤い て全体の平均より低い国は第一主成分の座標が負の值とな る。な扮，第 16 図は各国の第一主成分の座標を比較して例 えば日本はアメリカより 1.5 倍優れているといった見方は できず，あくまで各国の相対的な位置から順位付けを行っ て評価するものである.

以上のことを踏まえて第 15 図と共に第 16 図を見ると, 総合評価第 1 位は日本であり, これはフルサクセス達成数 の多さで評価されていることが分かる．また，第 2 位のア メリカは打上数とミニマムサクセス達成数で評価されてい ることが分かる。第 3 位のドイッは全体におけるほほ平均
的な位置にいる。フルサクセス達成により評価された国は 日本，カナダ，オランダ，コロンビアで，打上数とミニマ ムサクセス達成数で評価された国はアメリカ, デンマーク, スイス，トルコであった，目指すべき方向としては，図の 右下の第 4 象限となる.

\section{5. 考察}

まずCubeSat の打上数については，第 1 図から継続的 な増加傾向にあることが分かる。第 2 図及び第 7 図も併せ て見れば，未だ少数の国々ではあるが，段々と新規参入国 を増やしながら増加している，第 11 図よりこの傾向が続 けば 2014 年には年間 20 機の打上を超えるという，規模の 大きな動きになることが予測される。

一方, 衛星の打上数の増加が予測されても打上ロケット の確保には限度がある。第 3 図及び第 6 図を見れば，幾つ かの新規のロケットの他，最近になってピギーバックでの 打上を行うようになったロケットも含まれ，現在既に打上 ロケットの分散化が進んでいることが読み取れる。衛星の 打上数の増加に伴ってロケットの打上機会も増加すれば良 いが，そうではない場合，衛星の打上数予測に基づいた口 ケット開発，ロケット打上計画が立てられることが期待さ れる。

ミッション達成の成否については，第 4 図及び第 5 図よ りミニマムサクセスについては高成績であるが，フルサク セスについては判明しているだけで明確な失敗と判断され るものが 3 割以上ある，第 9 図を見ればその成否の割合は 年々改善しているとは言えない。第 10 図からは特に成功 数が突出した国は見られず，第 12 図を見ると打上数に対 する成功数の比率はほぼ一定である。これは一つの国の中 で次々と新規参入の団体による衛星が打ち上げられており, 打上数は結果として増加するものの, 経験を活用しながら の打上数増加ではないことによると考えられる。もし一つ の国の中で開発や打上の経験，不具合情報等の実績を共有 することができれば，その国は全体として経験を蓄積・活 用することとなるため, 成功率の向上が見られるものと期 待される。

第 8 図を見ると特にPSLV と Dnepr で打ち上げたとき にミニマムサクセス，フルサクセスの達成率が極めて高い ことが分かる．軌道上の衛星の成否と打上ロケットの種別 とは相関は無く，また，いずれのロケットも突出して多く打 ち上げられたものではない.一つの可能性として 1 回の衛 星の打上数が多いロケットの場合, 複数の衛星開発グルー プが他グループの状況を見ながら開発を行い，更には共同 で打上手続きや初期運用を行うため情報の共有がなされ易 い状況が考えられる5)．実際にはすべてのグループが他グ ループとそのような関倸にあったとは言い難いが，例えば 欧州の CubeSat の場合には ESA からの技術指導があった ことがうかがえるため，その指導を通して実質的な情報や 実績の共有があったと言える. 4.3 節で述べたノルウェーの 例を見れば，共同開発に基づく実績の共有を前提とすれば 達成率向上が予測され，このことは複数の技術段階にある 
国々が共同することによって総体として発展して行くこと が期待される。

第 15 図と第 16 図より, 現在までにCubeSat の打上経 験のある国々の相対的な総合評価が明確になった。原点付 近は世界的な平均を表すので, 右半面に位置する日本やア メリカに対して打上数の少ない国々は左半面に位置してお り, 打上数やミニマム/フルサクセス達成数の増加によって 次第に右へと移動する。また，フルサクセス達成数が増加 すれば次第に下へ移動する。従って, 眓中において目指す べき方向は右下であり，日本は世界の CubeSat 開発におい て総合評価で先駆的な位置にあることが分かった。

\section{6. 結論}

本研究では公開情報を集計し, 統計的な分析を行うこと によって CubeSatの現状把握と将来予測を行った。 その結 果, 次の事項を見出した.

-CubeSat の打上数は継続的に増加傾向であり, 2014 年 には年間打上数 20 機に達する。

・打上ロケットは新規のものが登場すれば直ちにCubeSat 打上手段として用いられ，既に打上手段の分散化が進ん でいる. 従って CubeSat の打上数の増加に伴って, 口 ケットの打上機会も連動して増加することが期待される.

·CubeSat はミニマムサクセス達成では高成績であるが, フルサクセスでは 3 割程度しか成功と言えない状況であ
る。また，打上数の多少にかかわらず成功率はほぼ一定 である。これは衛星開発未経験の新規参入団体が継続的 に参加し, かつ, 新規参入団体は衛星開発経験団体の知 見を共有していないことに起因する。

・共同開発に基づく実績の共有を前提とすれば達成率向上 が予測され，このことは複数の技術段階にある国々が共 同することによって総体として発展して行くことが期待 される。

・日本は総合評価で先駆的な位置付けとなっている.

例えば第 16 図中での国々の年々の動きを見ることで本研究 で行った統計的分析を継続的に行えば，今後どのように宇 宙開発計画を進めるべきであるかの方針を立てることがで きる，そのためには今後も更に情報の収集を行い，統計的 分析に用いるデー夕項目の拡大とデー夕数の増大に努める ことで, 継続的かつ詳細に分析を行うことが肝要である.

\section{参 考 文 献}

1) Helvajian, H. and Janson, S.: Small Satellites: Past, Present, and Future, The Aerospace Press, El Segundo, California, 2008, 876pp.

2) OPAL Main Web Pages, http://ssdl.stanford.edu/opal/ [cited on Feb. 1, 2011]

3) 東京大学中須賀研究室: 東京大学 CubeSat プロジェクト, http:// www.space.t.u-tokyo.ac.jp/cubesat/ [cited on Feb. 1, 2011]

4) 東京工業大学松永研究室: 東工大 CubeSat CUTE-I, http://lss. mes.titech.ac.jp/ssp/cubesat/ [cited on Feb. 1, 2011]

5) 中須賀真一, 宮崎康行, 松永三郎: private communication, 2011. 